\title{
Carbon and nitrogen isotope ratios in zooplankton of the Bering, Chukchi and Beaufort seas
}

\author{
Donald M. Schell*, Bruce A. Barnett, Kimberly A. Vinette \\ Institute of Marine Science, University of Alaska Fairbanks, Fairbanks, Alaska 99775, USA
}

\begin{abstract}
Zooplankton from the Bering, Chukchi, and Beaufort seas and a transect across the Arctic Ocean were collected from 369 stations on 18 cruises in the years 1985-1990 and 1993-1995. Carbon and nitrogen isotope ratio analyses were performed on the major taxonomic groups present-calanoid copepods, euphausiids and chaetognaths. The sampled waters around Alaska were divided into 11 subregions based on water mass characteristics and the zooplankton statistically tested for significant differences in the isotope ratios. Within all regions, copepods were significantly more depleted in ${ }^{13} \mathrm{C}$ than euphausiids (average $\delta^{13} \mathrm{C}$ difference for copepods $=-1.1 \%$ than euphausiids), but showed no significant differences from euphausiids in $\delta^{15} \mathrm{~N}$ except in the eastern Alaskan Beaufort Sea where copepods were relatively enriched in ${ }^{15} \mathrm{~N}$. The greatest variability in isotope ratios was among geographic regions. All taxa tested were ${ }^{13} \mathrm{C}$-depleted in the eastern Beaufort Sea, the Arctic Ocean and in deep waters of the southwestern Bering Sea relative to the continental shelf waters of the Bering and Chukchi seas. The maximum enrichments were found in the southwestern Chukchi Sea and central Bering Sea shelf waters. The advection of water northward through the Bering Strait was evident as a plume of enriched zooplankton extending to the shelf break in the Arctic Ocean. In contrast, the $\delta^{15} \mathrm{~N}$ within taxa generally increased moving northward from the deep Bering Sea to the Chukchi Sea and eastward into the Beaufort Sea. The $\delta^{15} \mathrm{~N}$ values for chaetognaths were 2.5 to $3 \%$ more enriched than copepods or euphausiids in all locations, consistent with their carnivorous diet. Comparisons of zooplankton isotope ratios among years and cruises within the same region revealed no significant differences. Low $\delta^{15} \mathrm{~N}$ and $\delta^{13} \mathrm{C}$ values in zooplankton of the pelagic Bering Sea are presumed to result from the isotopic discrimination arising in the presence of high nutrient abundances and slow phytoplankton growth rates whereas depleted values in coastal waters of the Canadian Beaufort Sea presumably derive from Mackenzie River inputs of terrestrially derived carbon and nitrogenous nutrients with low ${ }^{15} \mathrm{~N}$ and ${ }^{13} \mathrm{C}$ abundances. The geographic heterogeneity in isotope ratios over short distances indicates a need for caution in the interpretation of isotope ratios in marine mammals and birds with regard to trophic status and habitat usage.
\end{abstract}

KEY WORDS: Stable isotopes $\cdot$ Bering Sea $\cdot$ Chukchi Sea $\cdot$ Beaufort Sea $\cdot \delta^{13} \mathrm{C} \cdot \delta^{15} \mathrm{~N} \cdot$ Euphausiids Copepods C Chaetognaths

\section{INTRODUCTION}

The Bering and Chukchi seas are highly productive areas of the world oceans, supporting vast commercial fisheries and large populations of marine birds and mammals. The food chains supporting these important resource species are based on correspondingly rich primary productivity and the consequent high zooplankton production (Springer et al. 1989, 1996, Walsh et al. 1989). In contrast, the Beaufort Sea north of

·E-mail: schel@ims.alaska.edu
Alaska is relatively less productive but provides important summer habitat for several migratory species of birds and marine mammals (Frost \& Lowry 1984). Over the past 2 decades, declines in the populations of top consumer species such as Steller sea lions, fur seals, harbor seals and sea birds have led to studies attempting to ascribe causes arising from 'bottom-up' or 'topdown' controls (Merrick et al. 1987, Pitcher 1990, Trites 1992, Springer 1993). Isotope ratios in consumer tissues and potential prey are being used as tools in assigning trophic status and pathways of energy flow from seasonal habitats 
Past studies have used carbon and nitrogen isotope ratios as tracers to investigate the nutrient dynamics and pathways of energy flow within these ecosystems (McConnaughey \& McRoy 1979, Dunton et al. 1989. Saupe et al. 1989, Schell et al. 1989). Dunton (1985) first described a $\delta^{13} \mathrm{C}$ gradient in zooplankton collected along an east-west transect across the coastal Beaufort Sea and Saupe et al. (1989) extended the sampled area to include the northern Bering and Chukchi seas and described the variations in carbon isotope ratios between general taxa of zooplankton. These latter studies found a range of 3 to $5 \%$ in $\delta^{13} \mathrm{C}$ values for zooplankton over the geographic area that was reflected in organisms at higher trophic levels from the different regions. Zooplankton from the Bering and Chukchi seas were enriched in ${ }^{13} \mathrm{C}$ relative to zooplankton in the western Beaufort Sea which, in turn, were enriched relative to zooplankton in the eastern Alaskan and Canadian Beaufort Sea. In all regions studied, euphausiids had higher $\delta^{13} \mathrm{C}$ values than copepods by a minimum of $1 \%$. Relative abundances of major taxa varied across the Beaufort Sea with copepods as the dominant taxon in the east and euphausiids in the west.

The carbon isotope ratios of the particulate organic matter in the world oceans varies significantly (e.g. Freeman \& Hayes 1992, Goericke \& Fry 1994). Particulate organic matter in the southern hemisphere shows a steeper carbon isotope gradient with latitude than those from similar latitudes in the northern hemisphere, with the most pronounced changes typically occurring across the subtropical convergence. Rau et al. (1989) suggested that changes in the concentration of carbon dioxide $\left[\mathrm{CO}_{2}(\mathrm{aq})\right]$ were most responsible for the geographical gradient, but Goericke et al. (1994) later showed that the relationship is complex and often partially independent of $\left[\mathrm{CO}_{2}\right]_{\text {aq }}$. Fry \& Wainwright (1991) found that ${ }^{13} \mathrm{C}$-enriched large-celled diatoms predominated in the Georges Bank continental shelf environment that were enriched with nutrients and provided optimal growing conditions. The slower growing and smaller phytoplankton species predominated under nutrient limited conditions, and were comparatively ${ }^{13} \mathrm{C}$-depleted. Francois et al. (1993) and Altabet \& Francois (1994) showed that the sharp transition in carbon isotope ratios at the Subtropical Convergence between the Southern Ocean and the Indian Ocean is also characterized by a sharp transition in nitrogen isotope ratios, implying that phytoplankton growth rates, as well as nutrient supply and $\left[\mathrm{CO}_{2}\right]_{\mathrm{aq}}$, are important in establishing the isotopic regimes in the marine environment. Recently Laws et al. (1995) demonstrated a joint dependence of $\delta^{13} \mathrm{C}$ on phytoplankton growth rates and dissolved carbon dioxide concentrations with good agreement between theoretical and measured results for both laboratory cultures and in the subtropical ocean. The role of growth rates in establishing isotope ratios has been further strengthened by Bidigare et al. (1997) who showed very close correlations in haptophyte $\delta^{13} \mathrm{C}$ with phosphate concentrations at several sites in the world's oceans. Rau et al. (1996) have refined a phytoplankton growth model to take into account the various factors governing intracellular $\left[\mathrm{CO}_{2}\right]$ which in turn affects carbon isotope fractionation.

Based upon the literature and hydrographic data, we hypothesized that the proximity of deep nutrient-rich pelagic waters adjacent to a productive shallow continental shelf with strong on-shelf advection should provide a marked contrast in primary productivity and, by inference, carbon and nitrogen isotope fractionation during uptake. We chose to test this hypothesis by comparing all zooplankton isotope ratio data collected over the region within general taxonomic groups, focusing on calanoid copepods and euphausiids as herbivores and chaetognaths as a planktonic carnivore. We also wished to test the hypothesis that zooplankton growing in regions of high primary productivity (primarily on-shelf) would be more enriched in ${ }^{13} \mathrm{C}$ and ${ }^{15} \mathrm{~N}$ than zooplankton from regions with known high nutrient - low chlorophyll concentrations (pelagic Bering Sea) and that the northward advection of Bering Shelf waters through the Bering Strait would be reflected in zooplankton isotope ratios typical of source waters. These data are being used to explain the large variations observed in isotope ratios in temporally deposited marine mammal tissues (claws, vibrissae, baleen) that feed over large areas in the region (Schell unpubl.).

Nitrogen isotope ratios in the marine primary producers reflect the $\delta^{15} \mathrm{~N}$ of the initial source of inorganic nitrogen, the isotopic fractionation during biotic uptake, and the fraction of the total nutrient supply consumed (Altabet \& Francois 1994). The $\delta^{15} \mathrm{~N}$ of upwelled nitrate, the most abundant nutrient in the North Pacific ecosystem, is approximately 5 to $7 \%$ (Miyake \& Wada 1967) and phytoplankton collected in midsummer on the continental shelf of the Bering and Chukchi seas averaged $6.1 \%$ (Schell unpubl. data). Offshore surface waters of the Bering Sea contain elevated nitrate concentrations throughout the summer (Shiomoto \& Ogura 1994). Phytoplankton growing in excess nutrients tend to have more depleted $\delta^{15} \mathrm{~N}$ because fractionation in maximized (Michener \& Schell 1994). In contrast to $\delta^{13} \mathrm{C}$, the $\delta^{15} \mathrm{~N}$ value of a consumer organism typically increases approximately 3 to $4.5 \%$ with each trophic level (Fry \& Sherr 1984, Minagawa \& Wada 1984, Hobson \& Welch 1992). The $\delta^{15} \mathrm{~N}$ of a consumer is thus affected by both the $\delta^{15} \mathrm{~N}$ of the initial phytoplankton sources and its trophic status (Minagawa \& Wada 1984). 
Carbon isotope ratios can be used as tracers of biological energy flow to upper trophic level consumers if the carbon sources are limited to 2 and have contrasting values. Transfer of $\delta^{13} \mathrm{C}$ between trophic levels is nearly conservative so the $\delta^{13} \mathrm{C}$ of an organism closely reflects the $\delta^{13} \mathrm{C}$ of its food (DeNiro \& Epstein 1978, Fry \& Sherr 1984). The whole body $\delta^{13} \mathrm{C}$ of the consumer is typically enriched by $<1.0 \%$ relative to diet (DeNiro \& Epstein 1978). If isotopic ratios differ among regions, isotope ratio analysis can be used to estimate food intake from the different regions by a migratory organism (Fry \& Sherr 1984, Schell et al. 1989).

The study region comprising the Bering Sea, the Chukchi and Bering Seas continental shelves and the Beaufort is shown in Fig. 1 with the bathymetric contours and major circulation patterns (Coachman et al. 1975, Springer et al. 1989). The Anadyr Current (AC), Bering Slope Current (BSC) and the Alaskan Coastal Current $(\mathrm{ACC})$ are the principal water masses flowing northward through the Bering Strait. Alaskan Coastal Current water originates in the southeastern Bering Sea and characteristically has lower salinity due to fresh water input from rivers. The Bering Slope and Anadyr waters originate south of St. Lawrence Island and are characterized by lower temperatures and high nutrient content. The Anadyr Current is an extension of the Bering Slope Current and acquires the high nutrient content during deep winter mixing events (Coachman et al. 1975, Kinder et al. 1975). Water on the Bering shelf is mixed with Anadyr Current water at the frontal systems over the shelf break (Coachman 1986). Nutrients are conserved below the euphotic zone until they reach the shallower northern Bering Sea and southern Chukchi Sea where they support intense phytoplankton growth in the summer months. In contrast, the southwestern Bering Sea and adjacent waters of the North Pacific Ocean are characterized by high surface nutrient values over much of the year (Conkwright et al. 1994). In addition, turbulent flow through the Aleutian Island passes results in high surface nutrient concentrations throughout the summer season. Carbon dioxide $\left(\mathrm{pCO}_{2}\right)$ data are limited for the Bering Sea but late summer data show widespread undersaturation (Park et al. 1974) with the most negative values in the Gulf of Anadyr on the northwestern shelf. The eastern half of the continental shelf showed higher $\mathrm{pCO}_{2}$ values with maxima in the Aleutian Island passes.

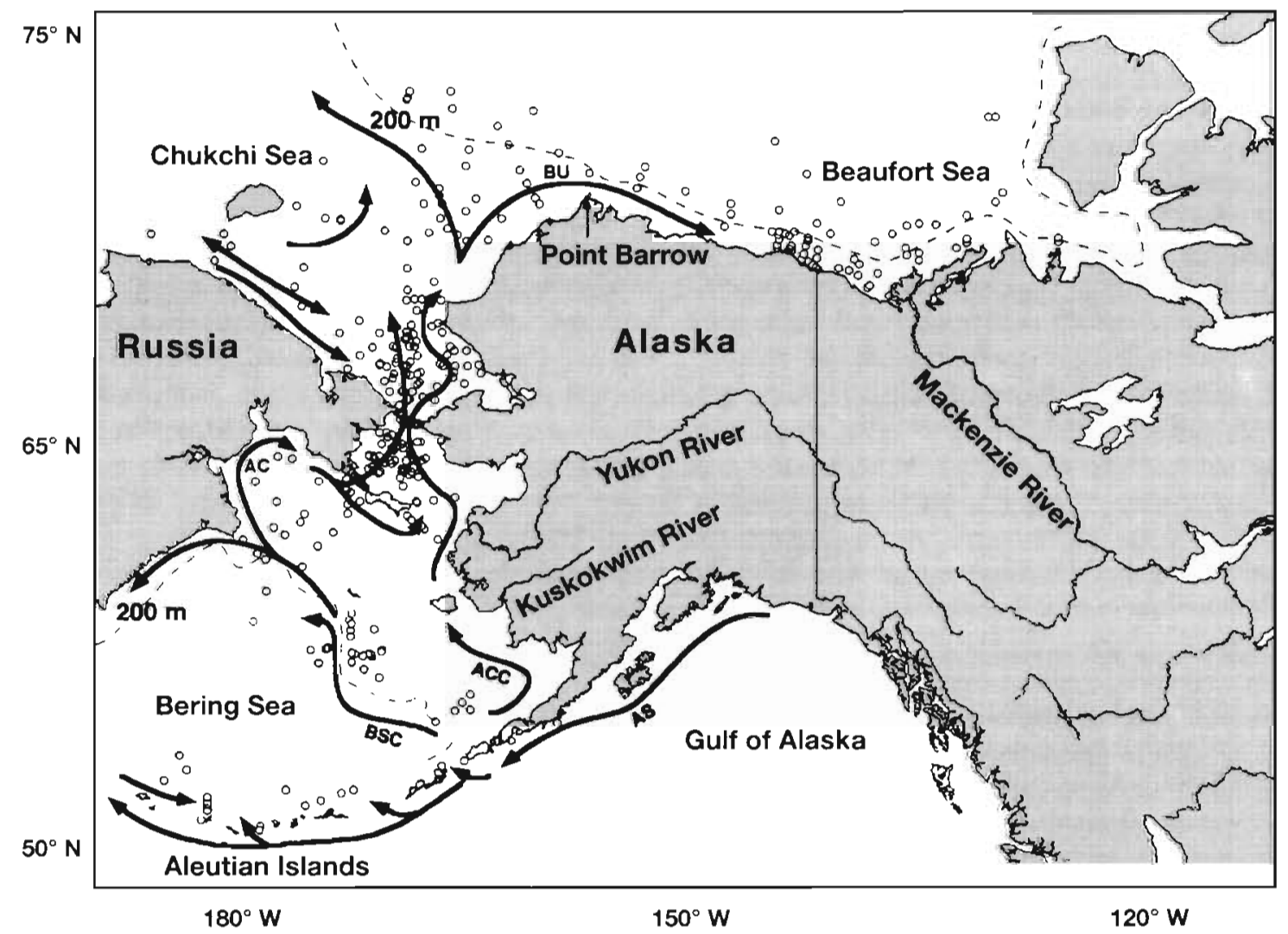

Fig. 1. Study region with station locations, continental shelf break and major circulation patterns indicated. Major currents are AS: the Alaska Stream; BSC: the Bering Slope Current; ACC: the Alaska Coastal Current; AC: the Anadyr Current; and BU: the Beaufort Undercurrent 
The active transport of water on-shelf and the resulting stabilization of the water column improve the growth environment for phytoplankton with resulting changes in the carbon and nitrogen isotope ratios as uptake depletes nitrogenous nutrients and carbon dioxide. During summer, warmer water masses comprised of the Alaskan Coastal Current and the higher salinity Bering Sea shelf and Anadyr waters pass through the Bering Strait and move northward and spread, with part moving past Point Barrow and entering the Beaufort Sea as an undercurrent (Mountain 1974, Aagaard 1984, Fissel et al. 1987). In transit, the Alaskan Coastal Current mixes with the surface water and can be traced to $147^{\circ}-148^{\circ} \mathrm{W}$, while the Bering Sea water, which has a deeper temperature maximum, can be traced to $143^{\circ} \mathrm{W}$ (Aagaard 1984). The Beaufort Sea also receives fresh water input from several rivers along the northern Alaskan and Canadian coast with approximately $80 \%$ of the total fresh water input being discharged by the Mackenzie River (Fissel et al. 1987). The Beaufort Sea is ice covered for 9 to $10 \mathrm{mo} \mathrm{yr}^{-1}$, with landfast ice forming in the fall and extending up to $50 \mathrm{~km}$ seaward by the end of winter. Along the shelf margin, currents move westward within the Beaufort Gyre and the deeper Bering Sea water flows eastward on the outer continental shelf (Norton \& Weller 1984). Ice cover may persist into July and significant open water is present only between July and September. Annual primary productivity of the Alaskan Beaufort Sea has been estimated to range between 16 and $36 \mathrm{~g}$ $\mathrm{C} \mathrm{m}^{-2} \mathrm{yr}^{-1}$ (Schell et al. 1984), including both ice algae and phytoplankton. Primary productivity in the Bering Sea has been estimated to range between 85 and $400 \mathrm{~g}$ $\mathrm{C} \mathrm{m}^{-2} \mathrm{yr}^{-1}$ (Iverson et al. 1979, Goering \& Iverson 1981, Springer et al. 1996) with the highest values aligned along the shelf break and northward in the Anadyr Current. The Bering Sea shelf is approximately $45 \%$ covered by sea ice between November and May with high interannual variability.

Zooplankton stocks in oceanic waters of the Bering Basin are highest in May-June and lowest in November while shelf zooplankton stocks are lowest in spring and highest in late summer (Cooney 1981). A majority of the oceanic population overwinters at depth and the large calanoid copepods Calanus cristatus and $C$. plumchrus reproduce without feeding in late winter (Cooney 1981). The young rise to the surface prior to the spring bloom. The smaller species of shelf copepods Pseudocalanus sp. and Acartia longiremis produce several generations of young while $C$. marshallae young are produced in the summer. The shelf zooplankton population is greatest in late summer and fall and includes oceanic euphausiids and large calanoid copepods which are carried onto the shelf and northward in what has been described as a displaced oceanic community (Cooney \& Coyle 1982, Springer et al. 1989). The sampling of zooplankton in the latter part of the summer and early fall was therefore anticipated to reflect the average isotope ratios resulting from the previous seasonal primary production.

\section{METHODS}

Zooplankton collection. Zooplankton samples were collected on 18 cruises undertaken by research vessels and the U.S. Coast Guard (USCG) icebreaker 'Polar Star' operating in the Bering, Chukchi and Beaufort seas between 1985 and 1994. Sampling occurred during the entire open water season but predominantly in the late summer/early fall. Additional samples from the Arctic Ocean were collected on the joint US-Canadian icebreaker transect of the USCG 'Polar Sea' and Canadian Coast Guard Ship (CCGS) 'Louis S. St. Laurent' in summer 1994 and from the CCGS 'John A. Macdonald' in August 1995. Samples from the southern Bering Sea and in the vicinity of the Aleutian Islands were collected in June 1995. Station locations are depicted in Fig. 1 including those reported by Saupe et al. (1989) to complete the geographic coverage.

Samples of zooplankton were collected with vertical or oblique net tows at each station. Bongo nets or $1 \mathrm{~m}$ ring nets of $505 \mu \mathrm{m}$ mesh were deployed to approximately $50 \mathrm{~m}$ depth or to within 5 to $10 \mathrm{~m}$ of bottom depth in shallower areas and ascended through the water column at a rate of $5 \mathrm{~m} \mathrm{~min}^{-1}$. If possible, zooplankton from each station were sorted at sea and subsamples taken of calanoid copepods, euphausiids and chaetognaths. Otherwise, samples were frozen and sorted in the laboratory. Other taxa, although common at some stations, were not collected with enough consistency to allow comparisons among most locations. Crab zoea, ctenophores, jellyfish, hyperiid amphipods, ampeliscid amphipods and fish larvae were abundant in some tows. Copepods, however, typically comprised over $50 \%$ of the total number of organisms from each net tow and, depending upon location, included 1 or more of the following calanoid copepods as well as other unidentified species: Calanus marshallae, C. glacialis, C. hyperboreus, Pseudocalanus minutus, Eucalanus bungii bungii, Neocalanus plumchrus, $N$. crista. tus. Metridia lucens was often present but was not included in statistical comparisons since this species is omnivorous or carnivorous. As a carnivore, $M$. lucens would be expected to have higher $\delta^{15} \mathrm{~N}$ values than herbivores. For statistical purposes, copepods were combined together for each station and an average $\delta^{13} \mathrm{C}$ value determined (with the exception of $M$. lucens). Once sorted, individual samples were either dried or frozen until processed in the laboratory. 
Euphausiids species present included primarily Thysanoessa raschii and $T$. inermis. Euphausiids were not present in samples collected in the deep Arctic Ocean and were not present in all samples collected in the eastern Beaufort Sea. Initially, copepods and euphausiids were sorted to large and small sizes, but no significant differences in isotope ratios were detected among sizes within a station. Subsequently no distinctions were made on size and zooplankton from each station were grouped only by taxa.

The chaetognaths collected were not identified to species at most locations. Samples from the Bering Sea and Chukchi Sea contained almost exclusively Sagitta elegans.

Zooplankton sample preparation. Sorted zooplankton samples were acidified with a few drops of $10 \%$ hydrochloric acid to remove any carbonates and dried to a constant weight at 80 to $90^{\circ} \mathrm{C}$. No lipids were extracted as the data were also being used to assess food consumption by marine mammals from different habitats. Although lipid content can vary greatly by season and extracted lipids typically have lower $\delta^{13} \mathrm{C}$ values than whole animals, the collection of samples during late summer-early fall would minimize seasonal effects. Isotope ratios run on a suite of lipid-free versus unextracted copepods samples from across the coastal Beaufort Sea confirmed that the primary isotope changes were not due to lipid content although the samples containing lipids had lower $\delta^{13} \mathrm{C}$ values than extracted samples (Dunton 1985).

Prior to 1993, samples were prepared manually for mass spectrometry by closed tube combustion followed by cryogenic separation of the liberated nitrogen gas and carbon dioxide as described in Saupe et al. (1989). The gas samples were stored in glass tubes until individual analysis on a VG Isogas SIRA Series 2 mass spectrometer. From 1994 onwards, all dried zooplankton samples were run directly on a Europa continuous flow mass spectrometry system which determines both $\delta^{13} \mathrm{C}$ and $\delta^{15} \mathrm{~N}$ on the same sample.

Statistical treatment of isotope ratio data. The Arctic Ocean transect data (Fig. 2) comprised a single line of stations across the Arctic and the pelagic stations were grouped for statistical comparison. The stations were segregated into on-shelf, slope and pelagic groups.

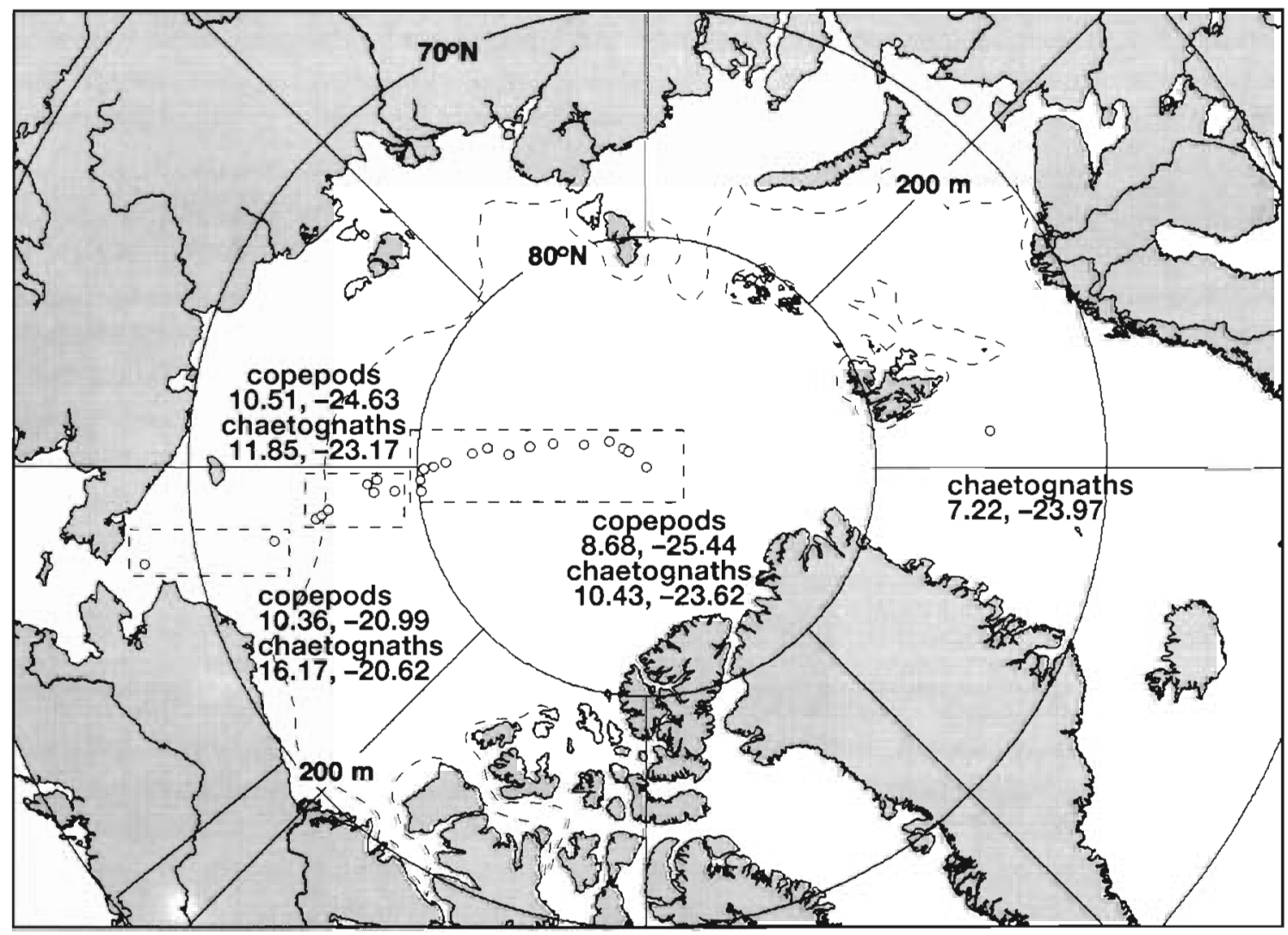

Fig. 2. Station locations and average isotope ratios $\left[\delta^{15} \mathrm{~N}\right.$ (positive values) and $\delta^{13} \mathrm{C}$ (negative values)] for zooplankton collected on the U.S.-Canadian transpolar transect by the USCG 'Polar Sea' and the CCGS 'Louis S. St. Laurent', summer 1994. Samples were grouped into on-shelf, continental slope and pelagic regions as indicated by boxes. The single sample of chaetognaths collected east of Greenland is shown separately 
The data from the 1 station east of Greenland are reported separately. Averages of $\delta^{15} \mathrm{~N}$ and $\delta^{13} \mathrm{C}$ were then determined for chaetognaths and copepods. Euphausiids were present only in the Chukchi Sea sample and these data were included in the northern Chukchi set.

The marine waters surrounding Alaska and the Arctic Ocean were divided into 11 regions (see Fig. 3) at the approximate boundaries of the principal water mass types (Fig. 1) for statistical comparisons. Single Classification Analysis of Variance was used to detect differences in the carbon and nitrogen isotopic abundances of each zooplankton group among the 11 geographic locations (Sokal \& Rohlf 1981). Multiple (unplanned) comparisons among the means were then performed using the GT-2 method for unequal sample sizes (Hochberg 1974). Significance was tested at the $\mathrm{p}=0.05$ level.

\section{RESULTS AND DISCUSSION}

\section{Euphausiid versus copepod enrichment}

The data in Table 1 allow comparison of average euphausiid and copepod $\delta^{13} \mathrm{C}$ and $\delta^{15} \mathrm{~N}$ values for 10 Chukchi/Bering/Beaufort sea regions (Fig. 3) for which both taxonomic groups were common to most sampling stations. For all areas, copepods were depleted in ${ }^{13} \mathrm{C}$ relative to euphausiids. The average copepod $\delta^{13} \mathrm{C}$ value was -22.74 for all samples and the average euphausiid $\delta^{13} \mathrm{C}$ value was -21.29 or a difference of $1.45 \%$. Analysis of variance and covariance with repeated measures also showed significant difference between copepods and euphausiids for 106 stations where $\delta^{13} \mathrm{C}$ values were available for both taxa. The increase in $\delta^{13} \mathrm{C}$ in euphausiids relative to copepods varied between 1.2 and $2.0 \%$ over the series of cruises.

Since lipids were not extracted from any of the zooplankton samples, the relative depletion in ${ }^{13} \mathrm{C}$ in copepods may be due to the much higher percentage of lipid carbon by weight. As noted earlier, lipid $\delta^{13} \mathrm{C}$ values were depleted relative to protein and chitin by up to several parts per thousand. Comparisons between regions shown in Fig. 4 are significantly different by at most the $p=0.05$ level if there are no overlaps between the bars.

In contrast to the carbon isotope ratios, nitrogen isotope ratios in euphausiids compared to copepods were not significantly dif- ferent among samples from the above regions with the exception of the Eastern Alaskan Beaufort Sea. Here, euphausiids were depleted in ${ }^{15} \mathrm{~N}$ relative to the copepod samples. Euphausiids tended toward lower $\delta^{15} \mathrm{~N}$ values eastward across the coastal Beaufort Sea whereas copepod $\delta^{15} \mathrm{~N}$ values remained $>9 \%$.

Figs. 5-7 present the contoured $\delta^{13} \mathrm{C}$ and $\delta^{15} \mathrm{~N}$ data for euphausiids, copepods and chaetognaths in the sampled areas using all available data. Whereas the regional values are useful in large scale assessment of energy and nutrient flow to fauna such as whales that migrate over long distances, the contoured data reveal the smaller scale variability possibly arising from cross-shelf advection and localized inputs of terrestrial carbon and nitrogen. Such data are helpful in assessing habitat usage by more localized marine mammal or seabird populations. Since some areas in the eastern Bering Sea and in the pelagic regions of the Bering Sea were not sampled or have few data points, the contour

Table 1. Average zooplankton isotope ratios, standard errors and number of samples for the subregions shown in Fig. 3. Significant differences are shown in Fig. 4. Blanks indicate taxa were not present in the sample

\begin{tabular}{|c|c|c|c|c|c|c|}
\hline Region & $\delta^{13} \mathrm{C}$ & SE & $\mathrm{N}$ & $\delta^{15} \mathrm{~N}$ & $\mathrm{SE}$ & $\mathrm{N}$ \\
\hline \multicolumn{7}{|l|}{ Chaetognaths } \\
\hline Canadian Beaufort & -23.8 & 0.25 & 17 & 11.9 & 0.59 & 15 \\
\hline East Alaskan Beaufort & -23.4 & 0.53 & 5 & 13.5 & 0.60 & 5 \\
\hline West Alaskan Beaufort & -20.2 & 0.09 & 6 & 14.2 & 0.29 & 5 \\
\hline Arctic Ocean & -23.5 & 0.17 & 11 & 11.1 & 0.45 & 11 \\
\hline North Chukchi & -20.3 & 0.09 & 43 & 13.3 & 0.19 & 40 \\
\hline East Chukchi & -20.5 & 0.13 & 36 & 12.3 & 0.30 & 27 \\
\hline West Chukchi & -19.9 & 0.15 & 28 & 12.2 & 0.34 & 26 \\
\hline East Bering & -21.0 & 0.15 & 33 & 12.9 & 0.30 & 35 \\
\hline Central Bering & -20.7 & 0.09 & 64 & 12.7 & 0.21 & 64 \\
\hline West Bering & -20.9 & 0.15 & 27 & 11.6 & 0.34 & 27 \\
\hline South Bering & -21.7 & 0.22 & 28 & 8.5 & 0.25 & 27 \\
\hline \multicolumn{7}{|l|}{ Copepods } \\
\hline Canadian Beaufort & -25.6 & 0.24 & 25 & 10.0 & 0.19 & 14 \\
\hline East Alaskan Beaufort & -25.7 & 0.20 & 57 & 10.8 & 0.19 & 45 \\
\hline West Alaskan Beaufort & -23.4 & 0.42 & 7 & 11.6 & 0.44 & 6 \\
\hline Arctic Ocean & -25.3 & 0.74 & 36 & 9.0 & 1.09 & 36 \\
\hline North Chukchi & -23.0 & 0.14 & 55 & 11.3 & 0.12 & 54 \\
\hline East Chukchi & -21.8 & 0.12 & 63 & 10.5 & 0.22 & 54 \\
\hline West Chukchi & -21.9 & 0.17 & 62 & 10.3 & 0.25 & 54 \\
\hline East Bering & -22.2 & 0.18 & 72 & 9.8 & 0.22 & 64 \\
\hline Central Bering & -22.1 & 0.13 & 143 & 9.6 & 0.17 & 132 \\
\hline West Bering & -21.9 & 0.18 & 65 & 8.7 & 0.19 & 64 \\
\hline South Bering & -23.2 & 0.18 & 88 & 5.8 & 0.21 & 87 \\
\hline \multicolumn{7}{|l|}{ Euphausiids } \\
\hline Canadian Beaufort & -23.7 & 0.18 & 5 & - & - & - \\
\hline East Alaskan Beaufort & -23.7 & 0.32 & 21 & 9.2 & 0.57 & 18 \\
\hline West Alaskan Beaufort & -22.1 & 0.29 & 19 & 11.2 & 0.27 & 21 \\
\hline Arctic Ocean & - & - & - & - & - & - \\
\hline North Chukchi & -21.5 & 0.12 & 42 & 11.0 & 0.18 & 36 \\
\hline East Chukchi & -20.2 & 0.16 & 38 & 9.7 & 0.28 & 33 \\
\hline West Chukchi & -20.7 & 0.20 & 31 & 9.9 & 0.28 & 32 \\
\hline East Bering & -20.9 & 0.19 & 35 & 10.0 & 0.22 & 33 \\
\hline Central Bering & -20.9 & 0.20 & 47 & 9.3 & 0.21 & 47 \\
\hline West Bering & -20.4 & 0.24 & 31 & 9.1 & 0.23 & 32 \\
\hline South Bering & -22.0 & 0.30 & 35 & 7.2 & 0.29 & 34 \\
\hline
\end{tabular}




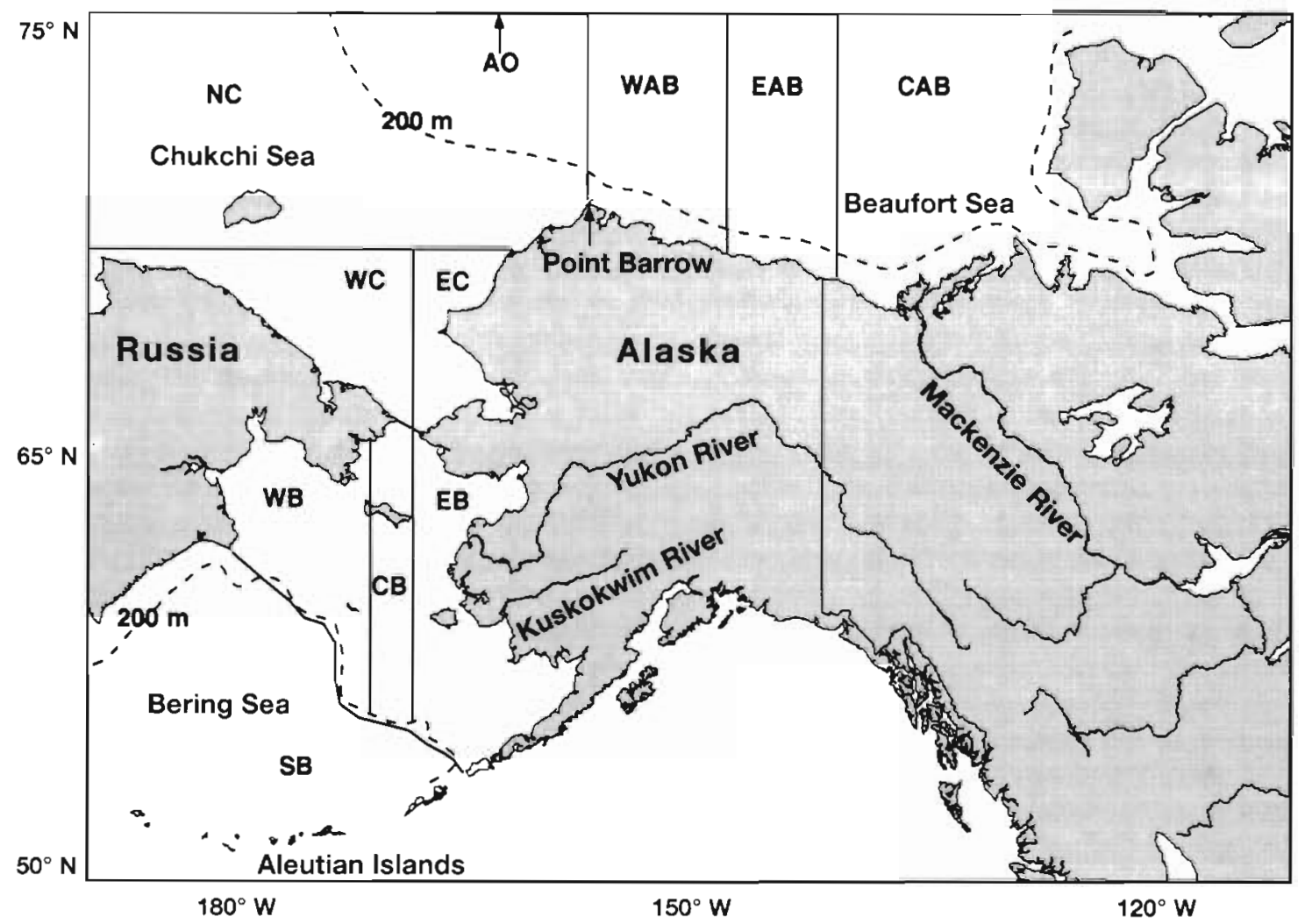

Fig. 3. Regions tested for statistical differences of isotope ratios among the general taxonomic groups listed in Table 1 and shown in Fig. 4. Regions are CAB: the Canadian Beaufort Sea; EAB: the eastern Alaskan Beaufort Sea; WAB: the western Alaskan Beaufort Sea; NC: the northern Chukchi Sea; WC: the western Chukchi Sea; EC: the eastern Chukchi Sea; WB: the western Bering Sea; CB: the central Bering Sea; EB: the eastern Bering Sea; and SB: the southern Bering Sea. AO: Arctic Ocean data are shown separately in Fig. 2

plots should be treated as approximations. The $\delta^{13} \mathrm{C}$ values for both euphausiids and copepods increase, progressing onto the continental shelves of the Bering Sea, and remain so northward into the Chukchi Sea. Further north, the lower values typify the shelf of the Beaufort Sea and depleted values in the Arctic Ocean. The other region of very low values is in the southwestern Bering Sea. Near the mouths of the YukonKuskokwim and Mackenzie rivers, regions of low $\delta^{13} \mathrm{C}$ values are also evident. Transitional zones such as along the coast of the Alaskan Beaufort Sea and over the continental slope of the Bering Sea showed the widest ranges of values whereas the on-shelf regions of the Bering and Chukchi seas were tightly grouped near $-22 \%$. The south Aleutian shelf copepod samples, although having more variability among samples, also averaged near $-22 \%$ and were indistinguishable from continental shelf Bering Sea samples.

The copepod samples from the eastern Beaufort Sea, the deep Arctic Ocean and pelagic regions of the Bering Sea showed very depleted $\delta^{13} \mathrm{C}$ values. Near the mouth of the Mackenzie River, values as low as $-27.5 \%$ were encountered with an average value of
$-26.1 \%$ and only in the pelagic waters of the Bering Sea were equally depleted samples obtained.

Carbon and nitrogen isotope ratios in herbivorous and carnivorous zooplankton exhibit pronounced geographic gradients in the waters surrounding Alaska. The results of the statistical analyses concur in general with the findings of Saupe et al. (1989) and Dunton et al. (1989) of trends in zooplankton enrichment from the Beaufort Sea to the Chukchi and Bering seas. However, the patterns of enrichment and depletion evident in Figs. 5 to 7 are quite complex. Pelagic waters of the western Bering Basin and the Arctic Ocean have copepods with pronounced depletions in both ${ }^{15} \mathrm{~N}$ and ${ }^{13} \mathrm{C}$. Onshelf advection and diffusion of nutrient-laden water northward in the Bering Sea are accompanied by rapid depletion of surface nutrients and an increase in the heavier isotope abundances, but $\delta^{13} \mathrm{C}$ increases are attained faster than $\delta^{15} \mathrm{~N}$. The $\delta^{13} \mathrm{C}$ values for both copepods and euphausiids reach maxima near the $200 \mathrm{~m}$ contour in the Bering Sea but the maximum $\delta^{15} \mathrm{~N}$ values for both taxa are not reached until near the Bering Strait. As the waters are advected through the Bering Strait and into the Chukchi Sea, the isotopic 


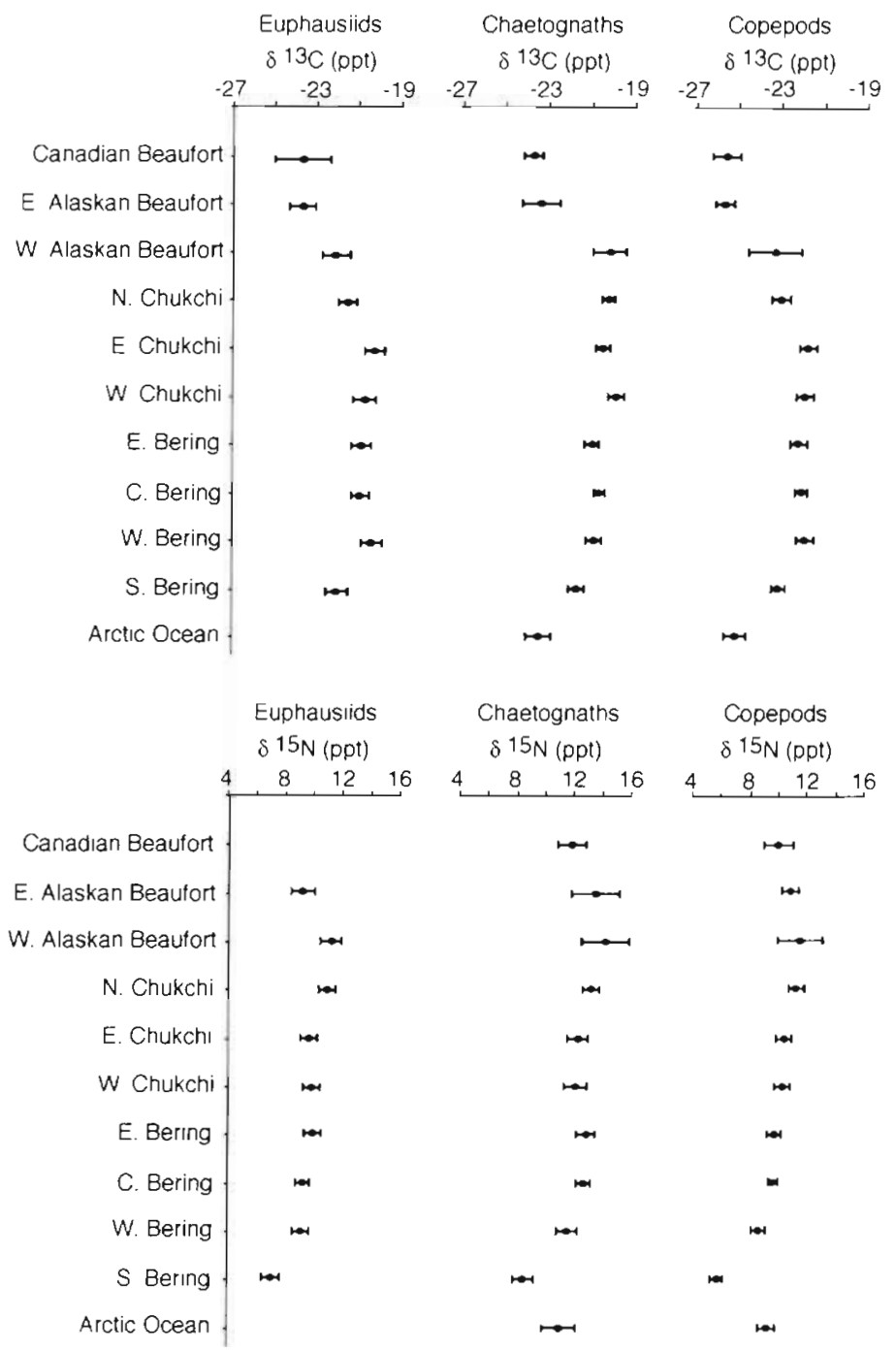

Fig. 4. Average values and $95 \%$ confidence limits on carbon and nitrogen isotope ratios in euphausiids, chaetognaths and calanoid copepods for the subregions shown in Fig. 3. Values are significantly different by $\mathrm{p}=0.05$ or less if no overlap occurs

signatures of euphausiids and chaetognaths are retained and these taxa are relatively enriched north to near the edge of the continental shelf and eastward to Point Barrow. High abundances of euphausiids are characteristic of the advected zooplankton in Bering/ Chukchi waters and we suspect that the specimens collected in the northern Chukchi Sea were transported into the region. Euphausids were not present in samples collected further north into the Arctic Ocean and rare in samples from the eastern Beaufort Sea.

Copepods contrast with the euphausiids in that the $\delta^{13} \mathrm{C}$ values reach maxima in the Bering Strait region and then decline in the northern Chukchi Sea and across the Beaufort Sea. We speculate that copepods are actively feeding in this region and reflect the decreased primary productivity and consequent increased fractionation against ${ }^{13} \mathrm{C}$ by ambient phytoplankton. The very low values of $\delta^{13} \mathrm{C}$ in copepods near the mouth of the Mackenzie River may reflect the freshwater inputs of river-transported organic matter of terrestrial origin $\left(\delta^{13} \mathrm{C}=-27\right.$ to $\left.-29 \%\right)$. The offshore waters of the Arctic Ocean were characterized by copepods and chaetognaths with uniformly ${ }^{13} \mathrm{C}$-depleted values near $-25 \%$ across the basin.

The $\delta^{15} \mathrm{~N}$ values for all taxa are relatively high $(>10 \%$ ) (Fig. 2) on the shelf and slope with decreasing values toward the pole. These high $\delta^{15} \mathrm{~N}$ values are acquired in the northern Bering Sea where surface nitrate concentrations approach zero and imply that nitrogenous nutrients are limiting from there northward but that efficient regeneration via grazing and excretion followed by rapid uptake retains the nitrogen in the water column. The slight loss of the heavier isotope through sinking of particulate matter in the central Arctic Ocean is assumed to cause the slow decrease in $\delta^{15} \mathrm{~N}$ in both copepods and chaetognaths approaching the Pole. Zooplankton in the vicinity of the Yukon and Kuskokwim river deltas in the eastern Bering Sea are also ${ }^{13} \mathrm{C}$-depleted, again reflecting the effects of terrestrial inputs of nutrients and carbon with low $\delta^{15} \mathrm{~N}$ and $\delta^{13} \mathrm{C}$ values.

The ${ }^{13} \mathrm{C}$ - and ${ }^{15} \mathrm{~N}$-depleted values of zooplankton collected in the vicinity of the western Aleutian Islands are indicative of slow phytoplankton growth rates and/or excess nutrient conditions. Although we obtained only limited nutrient concentration data during one of these zooplankton surveys (RV 'Alpha Helix', 1995), the data confirmed the presence of high surface nutrient concentrations-nitrate plus nitrite concentrations ranged from 14 to $30 \mu \mathrm{M}$ and phosphate concentrations ranged from 1.2 to $2.2 \mu \mathrm{M}$. These values are consistent with the trends mapped by Conkwright et al. (1994) showing high surface nitrate concentrations in the western Aleutians. Additional nutrient data from Japanese sampling (Shiomoto \& Ogura 1994) in the central Aleutian Basin and at the shelf break in July 1991 revealed nitrate concentrations ranging from approximately 3 to $17 \mu \mathrm{M}$ in surface waters in midJune to mid-July. As noted above, little data are available on $\mathrm{pCO}_{2}$ in the Bering Sea (summarized in Park et al. 1974) but our assumption here is that the interannual variations of $\mathrm{pCO}_{2}$ arising from physical processes at a given location are less important than the effects of phytoplankton production on $\delta^{13} \mathrm{C}$. These depletions are passed on to the carnivores as represented by chaetognaths and on to top consumers such as seabirds (K. Hobson pers. comm.). The depleted values are similar to the patterns observed in waters of the Southern Ocean where high dissolved carbon dioxide con- 
a

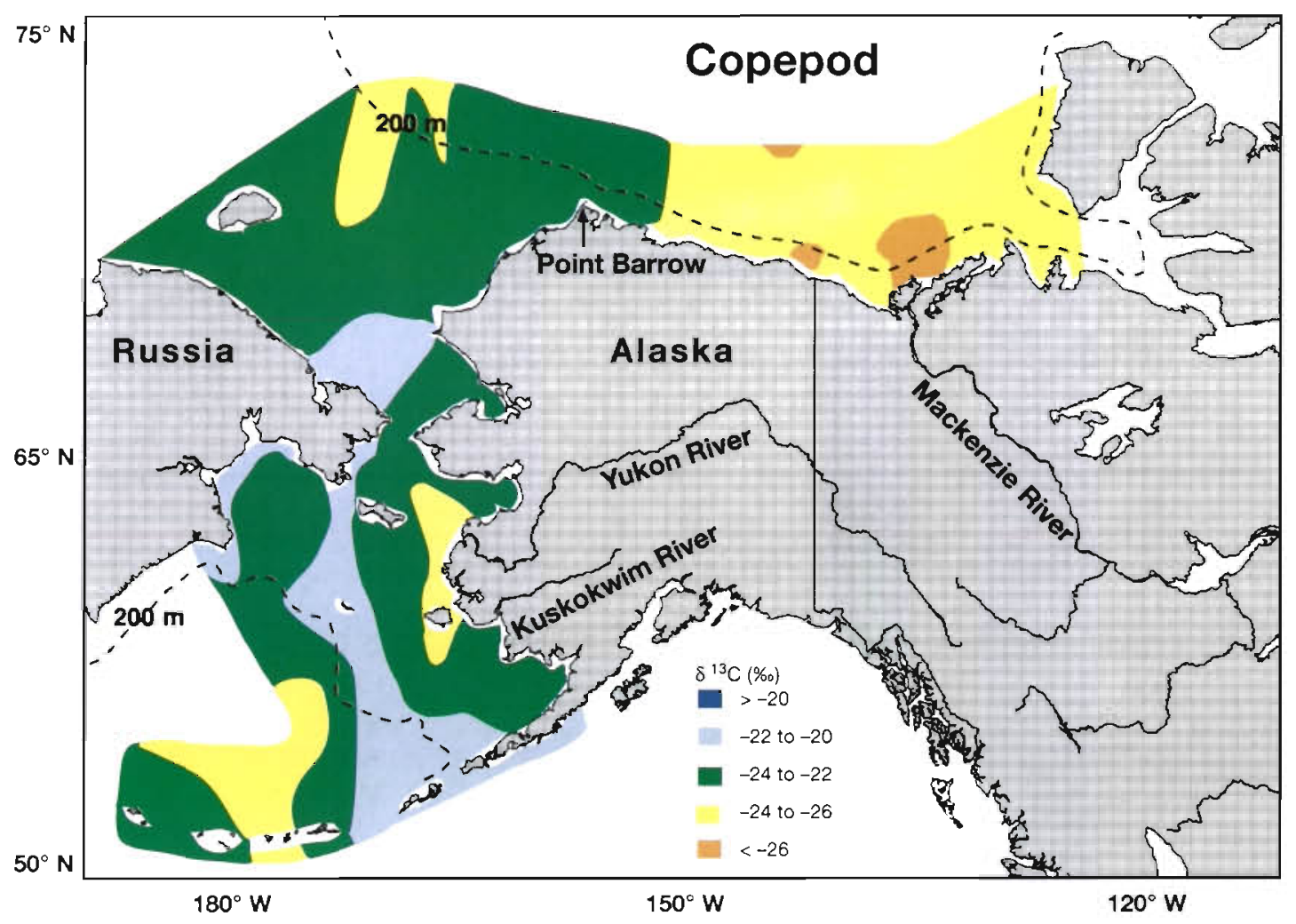

b

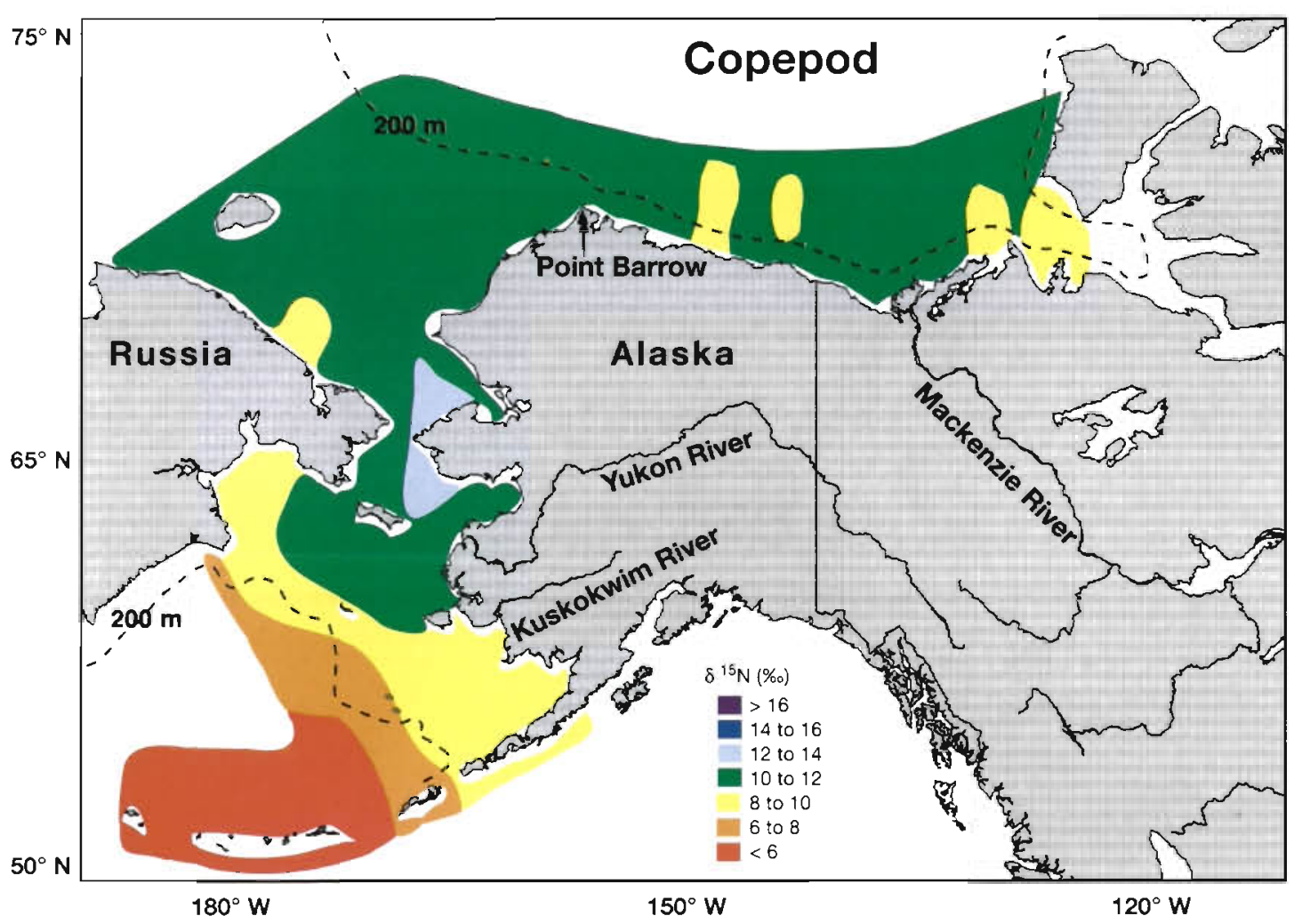

Fig. 5. (a) Carbon isotope ratios and (b) nitrogen isotope ratios in calanoid copepods 

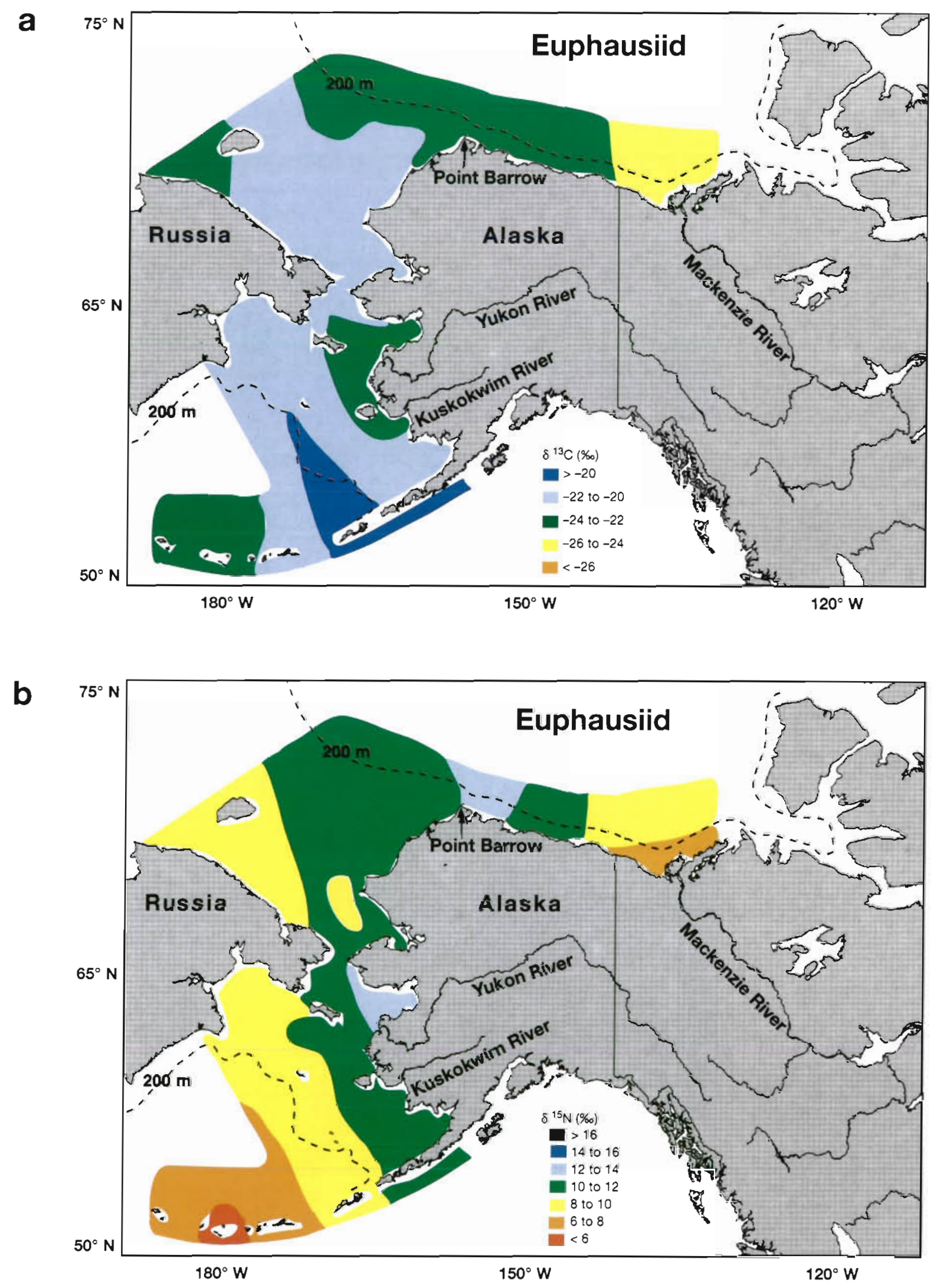

Fig. 6. (a) Carbon isotope ratios and (b) nitrogen isotope ratios in euphausiids 
a

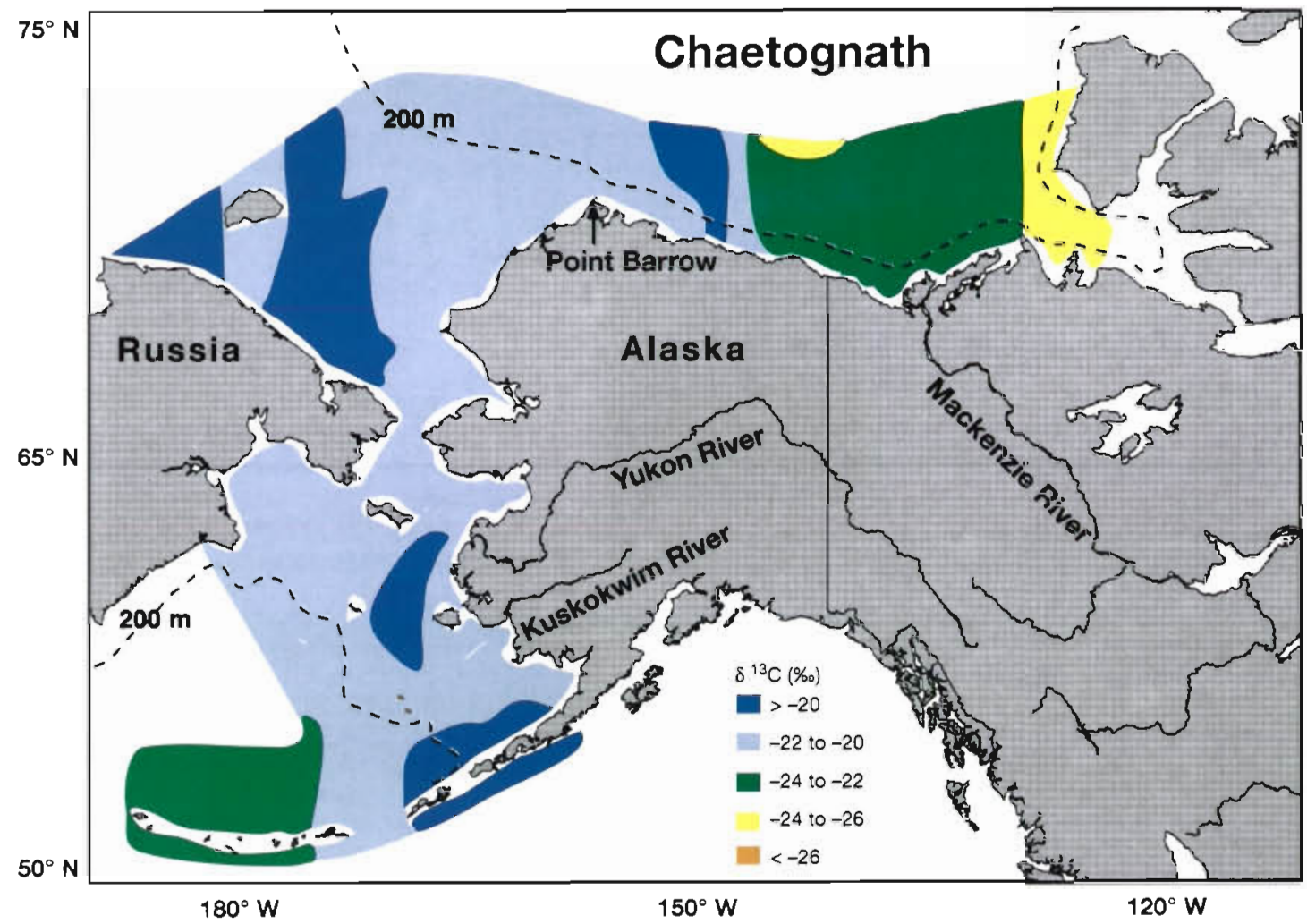

b

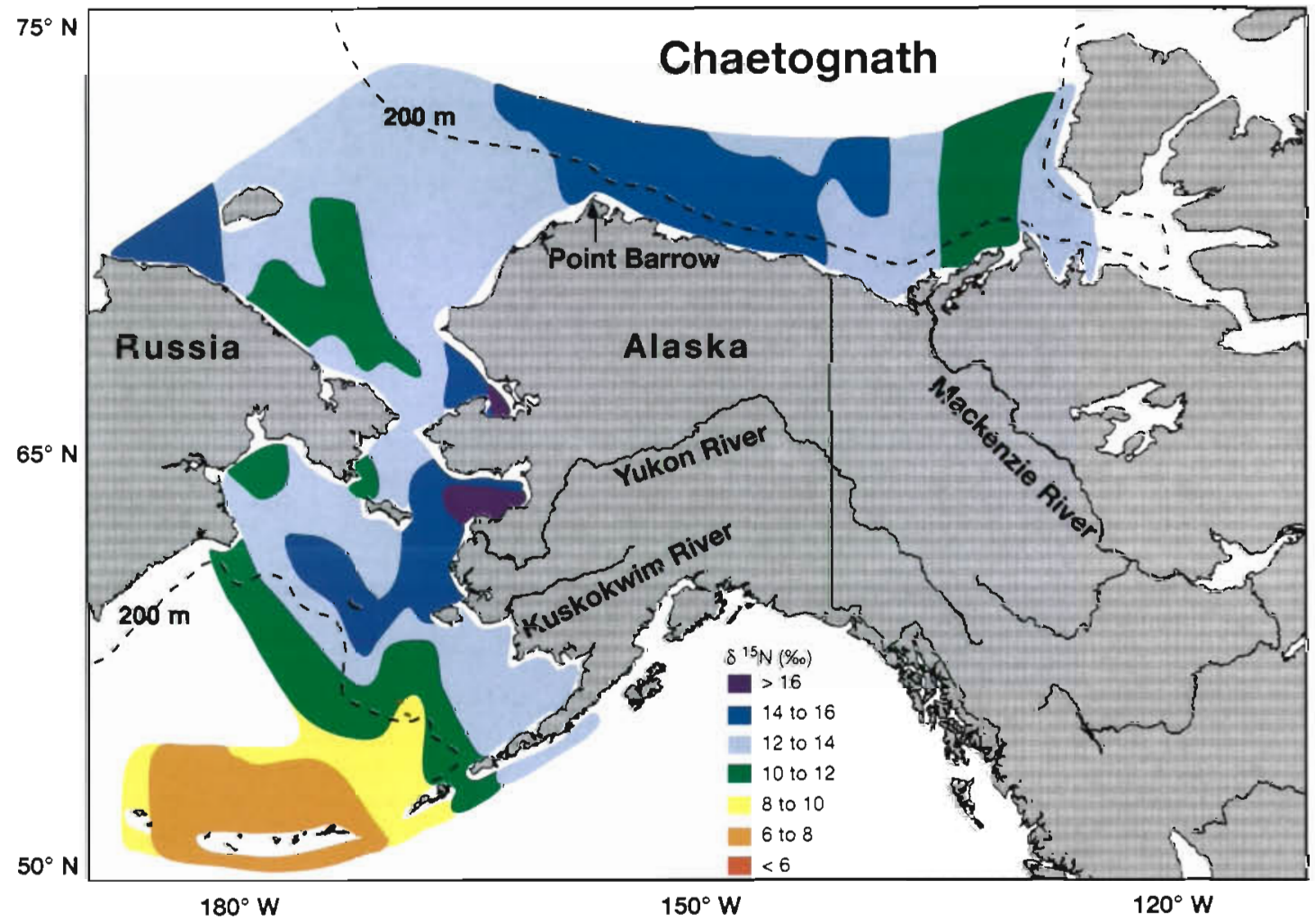

Fig. 7. (a) Carbon isotope ratios and (b) nitrogen isotope ratios in chaetognaths 
centrations and high surface nutrients (Rau et al. 1991a, b, 1992, Goericke \& Fry 1994) produce very low $\delta^{13} \mathrm{C}$ and $\delta^{15} \mathrm{~N}$ values in food web components.

The observed patterns in zooplankton isotope ratios can be explained in the context of phytoplankton growth rates in the existing environmental conditions. Factors such as deep wind-mixing and extensive cloud cover in the southwestern Aleutians can be expected to suppress phytoplankton growth rates and thus produce high isotope fractionation factors in phytoplankton. Rapid phytoplankton growth, primarily largecelled diatoms in shallow on-shelf waters, reduces fractionation (Fry \& Wainwright 1991) and produces the zones of ${ }^{13} \mathrm{C}$ enrichrnent in the northern Bering Sea and southern Chukchi Sea. Better definition of isotopic fractionation in primary producers acquired through laboratory cultures and proxy data from herbivores collected in the marine environment may help define regions of high or low seasonal primary productivity and to quantify temporal changes in regional primary production.

In summary, the carbon and nitrogen isotope ratios within taxa of zooplankton in Alaskan marine waters vary widely, apparently due to the effects of physical and chemical variables on primary producers. The data illustrate that the ranges in isotope ratios are indeed as large as found in Antarctic waters and often over much smaller distances. Assessing trophic levels or habitat usage by top consumers must be done cautiously and with accurate knowledge of the isotope ratio variations in potential feeding habitats arising solely from primary producers.

Acknowledgements. We thank M. Ramsay for collection of zooplankton from the trans-polar cruise (1994) and from the eastern Beaufort Sea (1995). Norma Haubenstock performed much of the mass spectrometry and sample collection and sorting. This work was supported in part by the U.S. Minerals Management Service, the NOAA-Outer Continental Shelf Environmental Assessment Program, the 'Exxon Valdez' Oil Spill Trustee Council and the Water and Environmental Research Center, University of Alaska Fairbanks.

\section{LITERATURE CITED}

Aagaard K (1984) The Beaufort undercurrent. In: Barnes PW, Schell DM, Reimnitz E (eds) The Alaskan Beaufort Sea: ecosystems and environments. Academic Press, Orlando, FL, p 47-71

Altabet MA, Francois R (1994) Sedimentary nitrogen isotope ratio as a recorder for surface ocean nitrate utilization. Global Biogeochem Cycles 8:103-116

Bidigare RR, Fluegge A, Freeman KH, Hanson KL, Hayes JM, Hollander D, Jasper JP, King LL, Laws EA, Milder J, Millero FJ, Pancost R, Popp BN, Steinberg PA, Wakeham SG (1997) Consistent fractionation of ${ }^{13} \mathrm{C}$ in nature and in the laboratory: growth-rate effects in some haptophyte algae. Global Biogeochem Cycles 11:267-278
Coachman LK (1986) Advection and mixing on the BeringChukchi shelves. Inner shelf transfers and rates report 1986, Inst. of Marine Science, University of Alaska Fairbanks

Coachman LK, Aagaard K, Tripp RB (1975) Bering Strait: the regional oceanography. University of Washington Press, Seattle

Conkwright ME, Levitus S, Boyer TP (1994) World ocean atlas 1994, Vol 1, Nutrients. NOAA Atlas NEDIS 1

Cooney RT (1981) Bering Sea zooplankton and micronekton communities with emphasis on annual production. In: Hood DW, Calder JA (eds) The eastern Bering Sea shelf: oceanography and resources, Vol 2. University of Washington Press, Seattle, p $947-974$

Cooney RT, Coyle K (1982) Trophic implications of cross-shelf copepod distributions in the southeastern Bering Sea. Mar Biol 70:187-196

DeNiro MJ, Epstein S (1978) Influence of diet on the distribution of carbon isotopes in animals. Geochim Cosmochim Acta 42:495-506

Dunton $\mathrm{KH}$ (1985) Trophic dynamics in marine nearshore systems of the Alaskan high Arctic. PhD dissertation, University of Alaska Fairbanks

Dunton KH, Saupe SM, Golikov AN, Schell DM, Schonberg SV (1989) Trophic relationships and isotopic gradients among western Arctic Ocean fauna. Mar Ecol Prog Ser 56: 89-97

Fissel DB, Marko JR, Birch JR, Borstad GA, Truax DN, Kerr R (1987) Water mass distributions. In: Richardson WJ (ed) Importance of the eastern Alaskan Beaufort Sea to feeding bowhead whales, 1985-6. U.S. Minerals Management Service Rep MMS87-0037. Available from National Technical Information Service, Springfield, VA 22161, as PB88150271/AF, p 11-131

Francois R, Altabet MA, Goericke R, McCorkle DC, Brunet C, Poisson $A$ (1993) Changes in the $\delta^{13} C$ of surface water particulate mater across the subtropical convergence in the SW Indian Ocean. Global Biogeochem Cycles 7:627-644

Freeman KH, Hayes JM (1992) Fractionation of carbon isotopes by phytoplankton and estimates of ancient $\mathrm{CO}_{2}$ levels. Global Biogeochem Cycles 6:185-198

Frost KJ, Lowry LF (1984) Trophic relationships of vertebrate consumers in the Alaskan Beaufort Sea. In: Barnes PW, Schell DM, Reimnitz E (eds) The Alaskan Beaufort Sea: ecosystems and environments. Academic Press, New York, p 381-402

Fry B, Sherr $E$ (1984) $\delta^{13} \mathrm{C}$ measurements as indicators of carbon flow in marine and freshwater ecosystems. Contrib Mar Sci 27:13-47

Fry B, Wainwright SC (1991) Diatom sources of $\delta^{13} \mathrm{C}$-rich carbon in marine food webs. Mar Ecol Prog Ser 76:149-157

Goericke R, Fry B (1994) Variations in marine plankton $\delta^{: 3} \mathrm{C}$ with latitude, temperature, and dissolved $\mathrm{CO}_{2}$ in the world ocean. Global Biogeochem Cycles 8:85-90

Goericke R, Montoya JP, Fry B (1994) Physiology of isotopic fractionation in algae and cyanobacteria. In: Ljatha $\mathrm{K}$, Michener RM (eds) Stable isotopes in ecology and environmental science. Blackwell Scientific, Boston, p 187-221

Goering JJ, Iverson RL (1981) Phytoplankton distribution on the southeastern Bering Sea shelf. In: Hood DW, Calder JA (eds) The eastern Bering Sea shelf: oceanography and resources, Vol 2. University of Washington Press, Seattle, p $933-946$

Hobson KA, Welch HE (1992) Determination of trophic relationships in a high arctic food web using $\delta^{13} \mathrm{C}$ and $\delta^{15} \mathrm{~N}$ analysis. Mar Ecol Prog Ser 84:9-18

Hochberg T (1974) Some generalizations of the T-method in 
simultaneous inference. J Multivar Anal 4:224-234

Iverson RL, Whitledge TE, Goering JJ (1979) Chlorophyll and nitrate fine structure in the southeastern Bering Sea shelf break front. Nature 281:664-666

Kinder TH, Coachman LK, Galt JA (1975) The Bering slope current system. J Phys Oceanogr 5:231-244

Laws EA, Popp BN, Bidigare RR, Kennicutt MC, Macko SA (1995) Dependence of phytoplankton carbon isotope composition on growth rate and $\left[\mathrm{CO}_{2}\right]_{a q}$ : theoretical considerations and experimental results. Geochim Cosmochim Acta 59:1131-1138

McConnaughey T, McRoy CP (1979) Food-web structure and the fractionation of carbon isotopes in the Bering Sea. Mar Biol 53:257-262

Merrick RL, Loughlin TR. Calkins DG (1987) Decline in abundance of northern seal lions (Eumetopias jubatus) in Alaska, 1956-86. Fish Bull (Wash DC) 85:351-365

Michener RH, Schell DM (1994) The use of stable isotopes in tracing marine aquatic food webs. In: Ljatha $\mathrm{K}$, Michener $R$ (eds) Stable isotopes in ecology and environmental science. Blackwell, London, p 138-157

Minagawa M, Wada E (1984) Stepwise enrichment of ${ }^{15} \mathrm{~N}$ along food chains: further evidence and the relation between $\delta^{15} \mathrm{~N}$ and animal age. Geochim Cosmochim Acta 48:1135-1140

Miyake Y, Wada E (1967) The abundance ratio of ${ }^{15} \mathrm{~N} /{ }^{14} \mathrm{~N}$ in marine environments. Rec Oceanogr Works Jpn 9:37-53

Mountain DG (1974) Preliminary analysis of Beaufort shelf circulation in summer. In: Reed JC. Sater JE (eds) The coast and shelf of the Beaufort Sea. Arctic Inst of N America, Arlington, VA, p $27-48$

Norton D, Weller G (1984) The Beaufort Sea: background, history and perspective. In: Barnes PW, Schell DM, Reimnitz E (eds) The Alaskan Beaufort Sea: ecosystems and environment. Academic Press, Orlando, FL, p 3-19

Park PK, Gordon LI, Alvarez-Borrego S (1974) The carbon dioxide system of the Bering Sea. In: Hood DW, Kelley E (eds) Oceanography of the Bering Sea. Occas Publ No. 2, Inst of Marine Science, University of Alaska

Pitcher KW (1990) Major decline in the number of harbor seals, Phoca vitulina richardsi, on Tugidak Island, Gulf of Alaska. Mar Mamm Sci 6:121-134

Rau GH, Ainley DG, Bengston JL, Torres JJ, Hopkins TL (1992) The relationship between organic matter $\delta^{13} \mathrm{C}$ and $\left[\mathrm{CO}_{2}(\mathrm{aq})\right]$ in ocean surface waters: data from a JGOFS Site in the Northeast Atlantic Ocean and a model. Geochim Cosmochim Acta 56:1413-1419

Rau GH, Hopkins TL, Torres JJ (1991b) ${ }^{15} \mathrm{~N} /{ }^{14} \mathrm{~N}$ and ${ }^{13} \mathrm{C} /{ }^{12} \mathrm{C}$

Editorial responsibility: Barry \& Evelyn Sherr (Contributing

Editors), Corvallis, Oregon, USA in Weddell Sea invertebrates: implications for feeding diversity. Mar Ecol Prog Ser 77:1-6

Rau GH, Riebesell U, Wolf-Gladrow D (1996) A model of photosynthetic ${ }^{13} \mathrm{C}$ fractionation by marine phytoplankton based on diffusive molecular $\mathrm{CO}_{2}$ uptake. Mar Ecol Prog Ser 133:275-285

Rau GH, Sullivan CW, Gordon LI (1991a) $\delta^{13} \mathrm{C}$ and $\delta^{15} \mathrm{~N}$ variations in the Weddell Sea particulate organic matter. Mar Chem 35:355-369

Rau GH, Takahashi T, DesMarais DJ (1989) Latitudinal variations in plankton $\delta^{13} \mathrm{C}$ : implications for $\mathrm{CO}_{2}$ and productivity in past oceans. Nature 341:516-518

Saupe SM, Schell DM, Griffiths WB (1989) Carbon-isotope gradients in the western arctic zooplankton. Mar Biol 103: $427-432$

Schell DM, Saupe SM, Haubenstock N (1989) Bowhead growth and feeding as indicated by $\delta^{13} \mathrm{C}$ techniques. Mar Biol 103:433-443

Schell DM, Ziemann PJ, Parrish DM, Dunton KH, Brown EJ (1984) Food web and nutrient dynamics in nearshore Alaska Beaufort Sea waters. U.S. Dept of Commerce, National Oceanic and Atmospheric Administration, OCSEAP Final Rep 25:328-499

Shiomoto A, Ogura M (1994) Biogenic silica in the Bering Sea gyre in summer. Proc NIPRI Symp Polar Biol 7:10-16

Sokal RR, Rohlf FJ (1981) Biometry, 2nd edn. WH Freeman Co, New York

Springer AM (1993) Report of the seabird working group. In: Keller $S$ (ed) Is it food? Addressing the marine mammal declines. University of Alaska, Alaska Sea Grant Report 93-01, p 14-29

Springer AM, McRoy CP, Flint MV (1996) The Bering Sea green belt: shelf-edge processes and ecosystem production. Fish Oceanogr 5:205-223

Springer AM, McRoy CP, Turco KR (1989) The paradox of the pelagic food webs in the northern Bering Sea. II. Zooplankton communities. Cont Shelf Res 9:359-386

Trites AW (1992) Northern fur seals: why have they declined? Aquat Mamm 18:3-18

Walsh JJ, McRoy CP, Coachman LK, Goering JJ, Nihoul JJ, Whitledge TE, Blackburn TH, Parker PL, Wirick CD, Shuert PG, Grebmeier JM, Springer AM, Tripp RD, Hansell DA, Djenidi S, Deleersnijder E, Henriksen K, Lund BA, Andersen P, Mueller-Karger FE, Dean K (1989) Carbon and nitrogen cycling within the Bering/ Chukchi Seas: source regions for organic matter affecting the AOU demands of the Arctic Ocean. Prog Oceanogr $22: 277-359$

Submitted: December 2, 1996; Accepted: September 23, 1997 Proofs received from author(s): February 5, 1998 